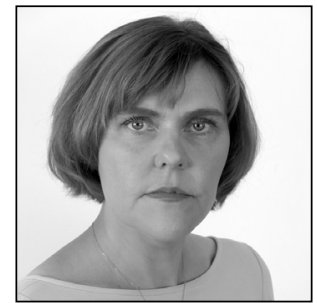

Julia Laffranque

\title{
The Ombudsman in the Eyes of the European Court of Human Rights
}

\section{Introduction}

The institution of the Ombudsman ${ }^{*_{2}}$ with a task of investigating maladministration of public authorities has its roots in Scandinavian/Nordic countries, Sweden being the pioneer in 1809 , followed by Finland in 1919. ${ }^{*}$ Now there are more than 140 Ombudsman institutions, around the world, in different models and with various tasks. ${ }^{*}$ Ombudsman institutions have played important roles in countries that have restored their democracy. Just to give an example, in Estonia, a special institution in charge of monitoring the adherence of public bodies to the law (and justice), the Chancellor of Justice (Õiguskantsler), was established in 1938, yet the functions of an Ombudsman were given to the same institution after Estonia regained its independence in the 1990s. ${ }^{*} 5$ Today, the Chancellor of Justice / Ombudsman also carries out functions of the national preventive mechanism under the Optional Protocol to the United Nations Convention against Torture and Other Cruel, Inhuman and Degrading Treatment or Punishment ${ }^{*}$ and acts as National Human

1 The paper reflects personal opinions only.

2 Although there are different terms used in different countries in relation to the Ombudsman institution, such as 'defender of rights', 'defender of people', and 'ombudsperson' to be more gender-neutral, or just 'ombuds' (coming from the Swedish and meaning 'to represent'), the term 'Ombudsman' (for the singular) is used throughout this article, as the most common and official term, and is employed to represent national and, if applicable, regional Ombudsmen as well as the European Ombudsman.

3 About the Ombudsman institutions in Europe, see: Gabriele Kucsko-Stadlmayer (ed), European Ombudsman-Institutions: A Comparative Legal Analysis Regarding the Multifaceted Realisation of an Idea (Wien; New York: Springer 2008). DOI: https://doi.org/10.1007/978-3-211-72882-6.

4 For details, see: 'Principles on the Protection and Promotion of the Ombudsman Institution ("The Venice Principles")' adopted by the European Commission for Democracy through Law (the Venice Commission) at its 118th Plenary Session (Venice, 15-16 March 2019) and endorsed by the Committee of Ministers at the 1345th Meeting of the Ministers' Deputies (Strasbourg, 2 May 2019), Opinion 897/ 2017, CDL-AD(2019)005.

5 Furthermore, it is important to note that the Chancellor of Justice is, according to the Constitutional Review Court Procedure Act, requested to give an opinion in cases involving review of constitutionality of laws by the Supreme Court. This aspect has also been noted by the Court; see, for instance: Raudsepp $v$ Estonia, 54191/07, s 40. There has been no legal debate as such about this procedure before the ECtHR, however.

6 'Optional Protocol to the Convention against Torture and Other Cruel, Inhuman or Degrading Treatment or Punishment' adopted on 18 December 2002 at the 57th session of the General Assembly of the United Nations by resolution A/RES/57/199 and entering into force on 22 June 2006. See: s 1(7) of the Chancellor of Justice Act, passed on 25 February 1999, RT I 1999, 29, 406, as amended RT I 2007, 11, 52 with entry into force on 18 February 2007. 
Rights Institution ${ }^{*}$, as do many Ombudsmen. Some countries also have introduced the institution of a regional Ombudsman. Ombudsmen have been awarded more and more new tasks; there are Children's Ombudsmen ${ }^{*}$, Data Protection Ombudsmen, etc.

The European Ombudsman, an impartial and constructive intermediary between individuals and European Union (EU) institutions to promote good administration, was created with the Maastricht Treaty in 1992 and started this work 25 years ago, in 1995. ${ }^{*} 9$

The European Court of Human Rights ('the ECtHR' or 'the Court' below) in Strasbourg was established in 1959 on the basis of the European Convention on Human Rights ('the ECHR' or 'the Convention') and is in charge of ensuring observance of the Convention by the 47 member states of the Council of Europe, who have all recognised the jurisdiction of the Court. On 1 November 1998, the Court became a full-time institution and the European Commission on Human Rights, which used to decide on admissibility of applications, was abolished.

Notwithstanding the fact that the work of an Ombudsman (whether the national or the European Ombudsman) and the ECtHR might look somewhat different, the rule of law, democracy, transparency, and access to documents, alongside migration issues and many more fundamental-rights-related topics, are at the focus of both institutions. Unlike a court, an Ombudsman can introduce investigations on his or her own initiative. However, unlike court judgements, the decisions of Ombudsmen do not have legally binding force. Irrespective of this dilemma - own initiative without binding decision or binding decision without own initiative - the common goal between Ombudsmen for Europe and the Court is to guarantee flawless protection of human rights in Europe. Of course, it would be interesting, for further steps in order to create a complete picture of the relations between 'defenders of rights' and 'renderers of justice' on European level, to have a closer look at the relations between the Ombudsman and courts as such on national level, as well as, on the other hand, between the European Ombudsman and the Court of Justice of the European Union (CJEU). This is out of scope for the present article, however.

The purpose of the present article is - by having a so-far unique closer look at the case law of the ECtHR related to Ombudsmen with regard to institutional, procedural, and substantial issues - to reveal how these institutions can more effectively contribute, in co-operation with each other, to best serving the above-stated common goal. One must admit that the case law of the ECtHR is not very extensive (this is true to a greater extent for the countries with long Ombudsman traditions) and there is quite little academic literature on this topic.

Therefore, inspired by these limited sources, with some particular emphasis on the ECtHR case law pertaining to the Ombudsman institution of Estonia, the structure of the article is based on the logic of the existing jurisprudence, looking first, institutionally, at whether the Ombudsman institution should be considered a remedy on national level that needs to be exhausted before one may turn to the Court. That discussion is followed by addressing this question: what is the role of the Ombudsman vis-à-vis the applicant before the ECtHR - could the Ombudsman intervene as a third-party amicus curiae, or, even more, could the Ombudsman represent a party who is incapable of self-representation? Further, in consideration of the procedure, it will be discussed whether the procedure before an Ombudsman should fulfil guarantees of a fair trial (Article $6 \mathrm{ECHR}$ ) and, if so, how. As to the substance, the discussion will look at what the impact of the Ombudsman is, both on national and on ECtHR level, on the further development of the case law on human rights. Albeit scarce, the case law of the Court regarding the European Ombudsman is introduced also.

7 UN General Assembly Resolution 48/134 of 20 December 1993, 'National Institutions for the Promotion and Protection of Human Rights'. See: s 1(10) of the Chancellor of Justice Act, passed on 25 February 1999, RT I 1999, 29, 406 as amended RT I, 3 July 2018, 14, with entry into force on 1 January 2019. The Chancellor of Justice performs the functions of protection of the rights of children and promotion thereof according to Article 4 of the Convention on the Rights of the Child.

8 See, for example, the European Network of Ombudspersons for Children (ENOC) website: https://enoc.eu/ (accessed 1 July 2020).

9 About the European Ombudsman, see, for example: Herwig C H Hofmann and Jacques Ziller (eds), Accountability in the EU: The Role of the European Ombudsman (Cheltenham: Edward Elgar Publishing 2017). DOI: https://doi. org/10.4337/9781785367311. 


\section{The Ombudsman and the European Convention on Human Rights System: Institutional Issues}

Firstly, let us look at some institutional issues that need to be dealt with: whether the Ombudsman institution is a remedy to be exhausted on national level and whether it as such is an effective remedy to enforce the ECHR rights. Also, can a national Ombudsman represent a party before the ECtHR and/or intervene as a third party?

\subsection{The Ombudsman - effective remedy on national level?}

Articles 34 and 35 of the Convention set the criteria for admissibility of an application to the ECtHR ${ }^{* 10}$, stipulating, among other things, that the Court may only deal with the matter after all domestic remedies have been exhausted.

Article 13 ECHR guarantees the availability at the national level of a remedy to enforce the substance of the ECHR rights and freedoms, and, to grant appropriate relief; the remedy must be effective in practice as well as law.

The question arises of whether referral to the Ombudsman institution is a domestic remedy to be exhausted prior to referral to the ECtHR as foreseen by Article 35 ECHR and whether notifications to the Ombudsman institution should be considered effective and accessible 'remedies' within the meaning of Article 13 ECHR.

In Montion $v$. France, ${ }^{*}{ }^{11}$ the applicant unsuccessfully turned to the French administrative courts to try to overturn a decree affecting his property (he was obliged to offer the municipal hunting association the use of his land such that all the hunters in the municipality could hunt on his land without him as the owner of the land being able to object). The applicant also complained to the French Ombudsman (Médiateur at that time) $)^{* 12}$, who made recommendations to a government minister for amendments to associated legislation (the legal base of the decree challenged by the applicant). In a letter, the Ombudsman informed the applicant that the Secretary of State for the Environment had rejected his suggestions for amendments to the law governing municipal hunting associations. Only after that did the applicant turn to the ECtHR, consisting at that time also of instances from the European Commission on Human Rights. The latter found the application inadmissible in 1987, stating that recourse to an organ that supervises administration, such as the Ombudsman, does not constitute an adequate and effective domestic remedy and that, since the final decision therefore was the judgment delivered by the French Council of State (Conseil d'Etat), the present application had been introduced well over six months after the date of the decision.

In Raninen $v$. Finland, ${ }^{*}{ }^{13}$ the applicant objected to military and 'substitute' civil service and was arrested several times. He complained only to the Ombudsman, who found that arrest lacked legal basis but that it did not call for ordering criminal proceedings against the military official involved. The ECtHR took note of the Ombudsman's response to the complaint and the fact that statutory actions for damages would not have been successful and rejected the government's objection of non-exhaustion, stating that existing remedies did not provide reasonable prospects of success and were not effective and adequate.

10 Admissibility criteria are set forth in articles 34 and 35 of the Convention, stipulating the right of individuals' application. An application may be filed with the Court by any individual or non-governmental legal entity located within the jurisdiction of a State Party to the Convention. He or she must be able to make out a case that he or she is a victim of a violation of the Convention. The Court may only deal with the matter after all domestic remedies have been exhausted, in accordance with the generally recognised rules of international law, and within six months from the date on which the final decision was taken. The Court does not deal with anonymous applications or with applications that are substantially the same as ones raising a matter that has already been examined by the Court or has already been submitted to another procedure of international investigation or settlement and contain no relevant new information. The Court declares inadmissible any individual application if it considers the application to be incompatible with the provisions of the Convention and its protocols; manifestly ill-founded, or an abuse of the right of individual application, or if the applicant has not suffered significant disadvantage. See, in more detail: European Court of Human Rights, 'Practical Guide on Admissibility Criteria' (latest update 31 August 2019). https://www.echr.coe.int/Documents/Admissibility_guide_ENG.pdf (accessed 1 July .2020).

11 Montion $v$ France, 11192/84, 14 May 1987.

12 The institution was changed by law in 2008-11 into défenseur des droits; see: https://www.defenseurdesdroits.fr/.

13 Raninen v Finland, 20972/92, 16 December 1997. 
In another Finnish case, Lehtinen $v$. Finland, ${ }^{*} 4$ the ECtHR declared the application inadmissible, stating that, as a general rule, a petition to the Ombudsman cannot be regarded as an effective remedy as required by Article 35 ECHR. The Court found that where the applicant makes a complaint to the Ombudsman and, at the same time, a court action with a legally binding result is available but was not initiated by the applicant, the domestic remedies have not been exhausted. The ECtHR stressed that, even though the Ombudsman of Finland can bring criminal charges against public servants, he or she has no power to quash or amend decisions made by administrative authorities. It distinguished the case from the Raninen case in that, because in Raninen neither criminal prosecution nor a civil action would have had reasonable prospects of success, there were no other remedies available than the Ombudsman.

In Egmez $v$. Cyprus, ${ }^{*} 15$ the applicant argued in national court that he had been a victim of treatment applied by police officers of the defendant state that was contrary to Article 3 ECHR (prohibition of inhuman or degrading treatment). The government claimed that the applicant had not exhausted all domestic remedies, because he did not use the judicial avenues offered by national law. The applicant, although he had not taken any other action, had turned to the Ombudsman, having been encouraged to do so by the Prosecutor General. The Ombudsman made an inquiry and published a report concluding that the applicant had been ill-treated. The Ombudsman had no power, however, to dictate what concrete measures should be taken by the executive or to apply sanctions to the responsible persons directly. Nevertheless, the ECtHR concluded that, since the Ombudsman's report was published, the state bodies had an obligation imposed by Article 3 ECHR to conduct their own investigations, which would have led not only to identifying those responsible - some of whom were already identified in the Ombudsman's report - but also to punishing them.

Yet it was the other way around in a further case: The Ombudsman had sent the applications of some of the applicants to the public prosecutor's office, and the question was whether this was sufficient to meet the requirements of exhausting domestic remedies. Namely, in Korobov and Others v. Estonia, ${ }^{* 16}$ each of the applicants made either an individual criminal complaint to the public prosecutor's office or application to the Chancellor of Justice (Õiguskantsler) / Ombudsman. The applicants complained that violence had been used against them during the riots in Tallinn in April 2007 that followed the protests against relocation of a monument commemorating the entry of the Soviet Red Army into Tallinn during the Second World War. ${ }^{*} 7$ The applicants also alleged that they had been unlawfully deprived of their liberty. The Ombudsman forwarded the applications submitted to him to the public prosecutor's office. With regard to the issue of whether domestic remedies had been exhausted, the applicants submitted that the Ombudsman had sent the applicants' applications to the prosecutor's office, as the applicants had done themselves. The applicants argued that it would be strange to suggest that they should have had better knowledge and understanding of the law than the Ombudsman. The ECtHR agreed with the applicants; it did not consider the applicants' choice of procedure in the circumstances of the case unreasonable. The Court rejected the Estonian government's plea of non-exhaustion of domestic remedies, because in the Court's view the applicants were not required to embark on another set of proceedings before the administrative courts that served substantially the same purpose.

In the case Leander $v$. Sweden, ${ }^{*} 18$ the applicant argued that he was entitled to receive all documents in the possession of national authorities on which basis they had issued a negative opinion on his ability to hold a certain position. He claimed a violation of Article 13 ECHR because he had not had the opportunity to address an independent competent authority for issuing of a binding decision on the communication in question. The respondent government indicated that the applicant would be able to lodge a complaint, domestically, about a violation of his right to the privacy guaranteed by Article 8 ECHR to 'the Chancellor of Justice' or to the Parliamentary Ombudsman. The ECtHR held that both of these authorities are competent to examine individual complaints to ensure that state organs apply the appropriate rules in force. In the exercise of their functions, these authorities have access to special information and are independent from the government. However, the ECtHR decided that such a 'national authority' should have the power to issue a binding ruling on the breach of Convention provisions asserted by the applicant and that in the

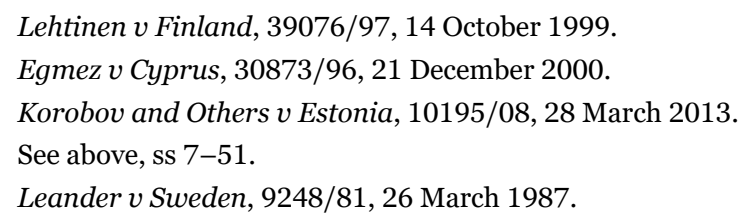


Swedish system both the 'Chancellor of Justice' and the Ombudsman, though independent, are not invested with powers of full adoption of 'binding judicial decisions', so from this point of view they do not meet the requirements imposed by Article 13 ECHR.

In the case T.P. and K.M. v. United Kingdom ${ }^{* 19}$, a complaint to the Ombudsman could have been made, but the ECtHR held that it would not have provided the applicants with any enforceable right to compensation. In E. and Others $v$. United Kingdom, ${ }^{2} 20$ among other remedies attempted, the applicants complained to the Ombudsman, who declined to investigate, citing statutory limitations to his jurisdiction. The ECtHR found that the Ombudsman process could not have resulted in a binding determination anyway.

Thus, beyond the particularities of each specific case, the jurisprudence of the ECtHR principally does not consider the Ombudsman to be an effective remedy within the meaning of Article 35, §1 ECHR, in general. Irrespective of the fact that in some countries Ombudsmen may have additional powers to bring cases before, for instance, constitutional courts, they nevertheless do not have powers to force changes - their role may assist with but not does not fulfil the existence of domestic remedies.

A complaint to the Ombudsman usually also does not constitute an effective remedy for the purposes of Article 13 ECHR, except in certain exceptional circumstances of fact; where judicial remedies are unavailable and the Convention right in question is not one of the core rights, the available non-judicial remedies, including the Ombudsman, may constitute an effective remedy. The prevailing factor, however, is that, since Ombudsmen do not have power to impose legally binding decisions on administrative authorities, their investigations do not constitute an Article 13 ECHR remedy. This is so even in cases wherein the national Ombudsman has additional powers to launch court cases, challenge constitutionality of laws, and prosecute officials.

An effective remedy is looked at in terms of the process in its entirety and, thereby, encompasses the availability of judicial processes provided by the state and court judgements arising out of a complaint, with the Ombudsman, of course, playing a supportive role in it. ${ }^{* 21}$

\subsection{The Ombudsman - representative of the applicant and/or third-party intervener?}

Let us now have a look at the national Ombudsman's role vis-à-vis the applicant before the ECtHR and possibilities for the Ombudsman to intervene as a third party.

If, in general, the Ombudsman institution is not a remedy to be exhausted before one turns to the ECtHR and if a complaint to the Ombudsman is not an effective remedy in terms of Article 13 ECHR either, is there any chance that an Ombudsman can make an application to the ECtHR on behalf of a victim, to protect human rights? This topic is connected to questions such as these: Would that entail full representation? Would that be in line with the tasks performed by a sample of Ombudsmen? Could an Ombudsman represent a person before the ECtHR even if he or she could not do so in national proceedings?

Article 34 ECHR permits any person, nongovernmental organisation (NGO), or group of individuals claiming to be a victim of a violation by one of the contracting parties to the ECHR or its protocols to file an application. In principle, Article 34 ECHR permits only 'victims' of Convention violations to make an application.

There have been some exceptional situations wherein third parties have been permitted to bring applications on behalf of a victim. Most often, these have been family members of deceased or minor victims or, on some rare occasions, non-governmental organisations (e.g., Centre for Legal Resources on Behalf of Valentin Câmpeanu v. Romania ${ }^{* 2}$, about the standing of a non-governmental organisation to file an application on behalf of a deceased mental patient).

It is an unanswered question in the case law of the ECtHR whether these exceptions could be expanded to include an Ombudsman. If this were to be possible in one case, what are the limitations of such

\footnotetext{
T.P. and K.M. $v$ United Kingdom, 28945/95, 10 May 2001; see judgment, s 109.

E. and Others $v$ United Kingdom, 33218/96, 26 November 2002, ss 45 and 76-77.

21 For further literature, see, for example: Simina Gagu, Aspects of the European Court of Human Rights Jurisprudence Regarding the Ombudsman; Linda C Reif, The Ombudsman, Good Governance and the International Human Rights System (Springer 2004) 125-36. DOI: https://doi.org/10.1007/978-94-017-5932-8.

22 Centre for Legal Resources on Behalf of Valentin Câmpeanu v Romania [GC] 47848/08, 17 July 2014.
} 
representation, and do they follow from the ECHR, national legislation, or both? If national legislation were, for example, to accept a national Ombudsman representing a person, would the ECtHR deny such a possibility? A parallel could be drawn with national or international NGOs representing applicants.

In the Inter-American human rights system, a human rights Ombudsman co-petitioned the InterAmerican Commission, which found the case admissible. ${ }^{* 23}$

In Europe, so far, the role of the Ombudsman is mostly limited to making a complainant aware of his or her right to turn to the ECtHR and informing him or her about the ECHR and ECtHR case law. This may even take the form of giving assistance in preparation of an individual's application if the person has not obtained legal assistance elsewhere.

Another option would be to allow Ombudsmen (particularly in their role as National Human Rights Institutions) to intervene as a third party and make amicus curiae submissions as is expressis verbis the case for the Commissioner of Human Rights of the Council of Europe before the ECtHR ${ }^{* 24}$. The Inter-American Court of Human Rights has accepted the mechanism of amicus curiae submissions by Ombudsmen ${ }^{*}$. According to Article 36 (2) ECHR, the President of the Court may, in the interest of the proper administration of justice, invite any person concerned who is not the applicant to submit written comments or take part in hearings. ${ }^{* 6}$ The Northern Ireland Human Rights Commission has intervened as a third party. ${ }^{* 27}$

Thus there is still room for Ombudsmen to intervene as amici curiae and exceptionally to represent a party, if the ECtHR would be willing to accept this.

\section{The Ombudsman and the European Convention on Human Rights System: Procedural Issues}

Let us now turn to some procedural issues by looking at whether the procedure before the national Ombudsman has had any impact on the Convention system. Even if the Ombudsman institution is not a remedy to be exhausted, there still can be cases of applications where the applicant has not only exhausted all domestic remedies but also sought advice from the Ombudsman or where the Ombudsman has on his or her own initiative reported on issues that later became relevant to the case before the ECtHR. The impact of the Ombudsman in substance is analysed further on; at this point, only some procedural connections are drawn. It is also important to examine how far the proceedings before the Ombudsman go toward meeting the criteria of a fair trial as set out in Article 6 ECHR and in ECtHR case law, and this is addressed later in the paper.

\subsection{Proceedings before Ombudsmen - impact on proceedings before the ECtHR?}

The following examples are all taken from the case law of the ECtHR concerning Estonia, as they are good illustrations of how the important role of the Ombudsman when coupled with the functions of the Chancellor of Justice has been taken into consideration by the parties and by the Court in deciding concrete cases. Of course, one could add to this list some of the cases discussed above, such as Raninen $v$. Finland and Egmez v. Cyprus.

The case Sorro $v$. Estonia ${ }^{* 28}$ involved publication of information about the applicant's prior employment with former security services. After regaining independence from the Soviet Union, in 1991, Estonia carried

23 See: Janet Espinoza Feria and Others $v$ Peru, 12.404, 10 October 2002.

24 See: Article 36(3) ECHR. See also: Dagmara Rajska and Zuzanna Rudzińska-Bluszcz, Ombudsperson Institutions in Europe: Their Role As Third Party Interveners before the ECHR and Their Initiatives before the Council of Europe (Examples of Poland, Sweden and Montenegro) (Cendon 2016) $55 \mathrm{ff}$.

25 See, for example: Yatama v Nicaragua, 23 June 2005, Seria C, no 127; Ticona Estrada v Bolivia, 27 November 2008, Seria C, no 193.

26 See also: Laurence Burgorgue Larsen, 'Les interventions éclairées devant la cour européenne des droits de l'homme ou le rôle stratégique des amici curiae' in Mélanges en l'honneur de Jean-Paul Costa. La conscience des droits - 1ère édition: La conscience des droits (Études, mélanges, travaux) (Dalloz 2011) 67-81.

27 Shanaghan $v$ UK, 37715/97, 4 May 2001.

28 Sóro v Estonia, 22588/08, 3 September 2015. 
out legislative reforms for transition to a democratic system. It passed the Disclosure Act in February 1995, under which information about the previous employment of individuals who had served in or co-operated with security or intelligence organisations of the former regime would be registered and made public. The applicant had been employed as a driver by the Committee for State Security (KGB) from 1980 to 1991. In February 2004, he received notice that he had been registered pursuant to the Disclosure Act and that an announcement would be published. He did not exercise his right to lodge a complaint, and the announcement was published in the paper and Internet versions of the State Gazette. The applicant subsequently challenged the notice in the administrative courts. Dismissing his complaint, the court of appeal accepted that the application of the Disclosure Act could interfere with a person's fundamental rights, but it was impossible to establish with absolute certainty decades later whether a specific driver had performed merely technical tasks or whether he had also performed substantive tasks. The applicant raised the issue with the Ombudsman, who addressed the Estonian Parliament with a report wherein he concluded that the Disclosure Act was unconstitutional, among others, in so far as all employees of the security and intelligence organisations were made public with no exception made in respect of the personnel who merely performed technical tasks. The Constitutional Law Committee of the Parliament disagreed with the Ombudsman. After the applicant had again addressed the Ombudsman, the latter replied (in 2006) with a letter stating that he did not deem it necessary to initiate constitutional review proceedings in respect of the Disclosure Act - the Ombudsman had in the meantime been briefed by the Estonian Internal Security Service and changed his mind.

The Estonian government pleaded before the ECtHR that the applicant had not exhausted all remedies. The government additionally suggested that the fact that the Ombudsman had expressed his opinion on the matter by the time court proceedings took place may have played a certain role in the domestic courts' assessment of the proportionality of the interference.

The ECtHR did not agree with the Estonian government and rejected the arguments on non-exhaustion. As far as the fact that the more recent (2006) opinion of the Ombudsman - according to which the Disclosure Act was constitutional - was known to the domestic courts while they were dealing with the case is concerned, the ECtHR observed that it is not for the Court to speculate whether the domestic courts would have decided the applicant's case differently if they had dealt with it before the Ombudsman gave his opinion. The ECtHR stated that, in any event, the Ombudsman's opinion was not binding on the courts, which were independent in deciding the case.

In Metsaveer $v$. Estonia, ${ }^{*}{ }^{29}$ the applicant made a petition to the Ombudsman, who replied by letter that he had established that the detention conditions in the Kuressaare arrest house did not meet the requirements necessary to upheld human rights. The Ombudsman had requested the Lääne Police Prefecture to take measures to ensure that the cells in the arrest house conform to the applicable requirements and that the inmates be given the possibility of being in the fresh air for at least one hour each day. The ECtHR took note of this.

In the case Tali $v$. Estonia, ${ }^{*}{ }^{*} 0$ a prison guard informed the applicant that he would be transferred to a punishment cell the very same evening to serve a disciplinary punishment. The applicant was dissatisfied, as he had been led to understand that he would not have to serve the punishment in question until the resolution of his complaint related to the matter by the Ombudsman. The prison guard told him that if he continued to object to going to the punishment cell, he would be taken there by force. The dispute triggered an incident that culminated in the use of pepper spray by the prison guards against the aggressive prisoner and his confinement to a restraint bed for more than three hours and that resulted in the ECtHR finding a violation of Article 3 ECHR. The Court did not have to take a stand, however, on whether the prison authorities should have waited until the resolution of the applicant's complaint by the Ombudsman.

Thus, in two of the three examples, the Court did not ignore the fact that the Ombudsman had been involved in one way or another in domestic proceedings; it even took note of what the Ombudsman had stated although engaging the Ombudsman was not a remedy to be exhausted and there were also domestic judgements in place. In the third case, the link to the Ombudsman is remote, as the Court decided anyhow that there was a violation of the ECHR without the need to answer the challenging question of whether an application pending before the Ombudsman would have allowed preventing the applicant from serving the disciplinary punishment.

29 Metsaveer $v$ Estonia [dec.] 12454/05, 26 June 2006.

30 Tali $v$ Estonia, 66393/10, 13 February 2014. 


\subsection{Procedure before the Ombudsman - are guarantees of a fair trial (Article 6 ECHR) applicable?}

The Court has dealt with several issues related to the right to a fair trial (Article $6 \mathrm{ECHR}$ ) in relation to the Ombudsman, such as problems with independence and impartiality of the Ombudsman, the absence of a public hearing before the Ombudsman, and a weak legal basis and non-publication/inaccessibility of the Ombudsman's decisions.

The case Heather Moor \& Edgecomb Limited (HME) $v$. UK ${ }^{*} 31$ is a good example of the Court's assessment of the applicability of the right to a fair trial with regard to the procedure before the Ombudsman. The case was, firstly, about the alleged failure of the Financial Ombudsman Service (FOS) to guarantee a fair and public hearing. Parliament established the FOS as a means of resolving certain consumer complaints quickly and with minimum formality. The rules governing the FOS's procedure provide no guarantee of an oral/public hearing; the parties can seek this, but it is at the Ombudsman's discretion. There is a presumption against a hearing. The ECtHR did not find such legislative policy inappropriate. According to the ECtHR in deciding on the complaint against the applicant, the Ombudsman determined the applicant's civil rights and obligations; the procedure before the FOS must therefore conform to the standards set down in Article 6 ECHR. The Ombudsman, by deciding whether to hold a hearing or not, took each decision in light of ECHR requirements and each time reasoned it. The ECtHR concluded that a hearing would not have imparted any additional fairness. The ECtHR logic was strained in placing considerable weight on the option of judicial review of an Ombudsman's decision, which was sought in the case at hand and ended up with oral arguments at the Court of Appeal resulting in a judgment that, inter alia, elaborated on whether there was a need for an oral hearing before the Ombudsman. The ECtHR concluded that the fact that proceedings are of considerable significance for an applicant is not decisive for the necessity of a hearing, the applicant had ample opportunities to present the case, and the facts and law could have been adequately addressed in written proceedings.

Secondly, the ECtHR also addressed the complaint about the non-publication of the Ombudsman's decision and found that, irrespective of the fact that publicity contributes to guarantees of a fair trial, special features of the proceedings have to be taken into account. In a contrast against certain types of cases, such as those involving children, there was no compelling reason to withhold the Ombudsman's decision from publication. The considerations of quickness and informality that are relevant to the holding of an oral hearing are not relevant to the public pronouncement of 'judgement'. However, looking at the domestic proceedings in this case in their entirety, the ECtHR agreed with the Court of Appeal's judgment, which quoted from the Ombudsman's final decision and achieved the purpose of Article 6 of the Convention.

Thirdly, the applicant complained about the legal basis of the Ombudsman's decision. The ECtHR considered that the scope of the Ombudsman's discretion is not so broad as to automatically contravene the principle of foreseeability that is an integral part of the rule of law. The Ombudsman's office explained in detail the basis for its decision. The ECtHR detected no sign of any arbitrariness in the procedure conducted by the Ombudsman and in the decision issued. The applicant was able to respond in detail to the provisional decision of the Ombudsman; therefore, it cannot be said that the final decision of the Ombudsman was unforeseeable. ${ }^{*} 32$

In the second case, Heather Moor \& Edgecomb Limited (HME) v. UK (No. 2) ${ }^{*} 33$, the ECtHR was again faced with a complaint about the fact that an FOS decision was not pronounced publicly and that the Ombudsman refused to hold an oral hearing and a cross-examination. The applicant further complained that the Ombudsman lacked structural independence and impartiality; lastly, relying also on Article 1 of Protocol No. 1 ECHR, the applicant complained that the FOS did not operate compatibly with the rule of law, its case law being neither accessible nor foreseeable. The ECtHR declared the application inadmissible (by a majority). Since the facts in the two Heather Moor \& Edgecomb Limited cases are similar, the ECtHR referred to the considerations developed in its previous decision. The ECtHR added that it is not for the

31 Heather Moor \& Edgecomb Limited (HME) v UK [dec.] 1550/09, 14 June 2011.

32 See also: RPC, 'FOS Does Not Breach Human Rights (7 July 2011). https://www.rpc.co.uk/perspectives/financial-servicesregulatory-and-risk/fos-does-not-breach-human-rights (accessed 12 April 2020); Herbert Smith Freehills LLP, 'European Court of Human Rights Considers the Compatibility of the Financial Ombudsman Service Process with Article 6 ECHR'. https://www.lexology.com/library/detail.aspx?g=976b200c-3cf6-4a49-af3d-1d5bcb3d0539 (accessed 12 April 2020).

33 Heather Moor \& Edgecomb Limited (HME) v UK (No. 2) [dec.] 30802/11, 26 June 2012. 
Court to take a view on the well-foundedness of the Ombudsman's decision - to do so would be tantamount to exercising a fourth-instance function.

The applicant argued that there was such a close structural connection between the Financial Services Authority (FSA) and the FOS that the latter's independence and impartiality were open to doubt. It referred to the fact that the chairman and directors of the FOS were appointed by the FSA, that the Chief Ombudsman reports to the FSA on the discharge of its functions; that the FSA controlled the FOS budget, and that FSA approval was required for the FOS rules of procedure. The ECtHR found that these assertions by the applicant were of a general character. The Court was not persuaded that the statutory relationship between the FSA and the FOS was such as to compromise or raise doubts related to the latter's independence and impartiality in deciding on individual complaints.

In the case Kalda $v$. Estonia, ${ }^{*}{ }^{34}$ the applicant, a prisoner, complained that he was prevented from carrying out legal research in consequence of being refused access to certain Internet sites, these including the site of the Ombudsman (Õiguskantsler). According to the applicant, he was involved in a number of legal disputes with the prison administration and needed access to those Internet sites so as to be able to defend his rights in court. The Estonian Supreme Court concluded by majority that detainees were able to contact the Ombudsman by mail and make a request for information, and it found no violation of the prisoner's right. The ECtHR found a violation of the applicant's right to receive information and that the denial of access to the websites of the Council of Europe Information Office in Tallinn, the Ombudsman (Chancellor of Justice), and the Estonian parliament was in breach of Article 10 ECHR (freedom of expression, the right to information). The Court noted that these websites, including the Estonian Ombudsman's website, predominantly contained legal information and information related to fundamental rights, including the rights of prisoners. For example, the website of the Õiguskantsler contained his selected legal opinions. The ECtHR considered that the accessibility of such information promotes public awareness and respect for human rights. The Court gave weight to the applicant's argument that the Estonian courts used such information and the applicant needed access to it for the protection of his rights in the court proceedings.

The ECtHR took note of the applicant's argument that legal research in the form of browsing through the available information (to find relevant information) and making specific requests for information were different matters. Indeed, for one to make a specific request, one would need to be aware of which particular information is available in the first place. The Court noted also that, while the domestic authorities had referred to alternative means of making available to the applicant the information stored on the websites in question (for example, by mail), they did not compare the costs of these alternative means with the additional costs that extended Internet access would allegedly incur. The Court went on to note that in a number of Council of Europe and other international instruments the public-service value of the Internet and its importance for the enjoyment of a range of human rights has been recognised. Internet access has increasingly been understood as a right, and calls have been made to overcome the 'digital divide'. More and more services and information are only available only via the Internet. The Court reiterated that under the Imprisonment Act prisoners have been granted limited access to the Internet via computers specially adapted for that purpose and under the supervision of the prison authorities. Thus, arrangements necessary for the use of the Internet by prisoners have in any event been made and the related costs have been borne. While the security and economic considerations cited by the domestic authorities may be considered relevant, the Court noted that the domestic courts undertook no detailed analysis as to the security risks or additional costs allegedly emerging from the access to the three additional websites in question.

Therefore, it can be concluded that the conditions for a fair trial as specified in Article 6 ECHR and the case law of the ECtHR are applicable to the procedure before the Ombudsman if the Ombudsman determines the applicant's civil rights and obligations, including (to a certain extent) dealing also with administrative cases as covered by the case law of the ECtHR under Article 6 ECHR, and possibly in cases in which the Ombudsman could in some way determine criminal charges. According to the existing case law of the ECtHR, among these rights are those to a public hearing, publication and accessibility of the decisions (including on the website), foreseeability, and reasoning of the decision of the Ombudsman. The Court has, however, made certain concessions with regard to strict application of these guarantees/criteria in so far as there are also possibilities of the matter decided upon by the Ombudsman being revised before the courts, and the Court has declined to express a view on the well-foundedness of the Ombudsman's decision.

$34 \quad$ Kalda $v$ Estonia, 17429/10, 19 January 2016. 
Certainly there could be many more issues, such as the question of reasonable time or the right to be heard and issues of representation in the Ombudsman proceedings that could lead to case law of the Court; however, these issues rarely reach the Court, mainly because recourse to the Ombudsman is not a remedy to be exhausted on national level.

\section{The Ombudsman and the European Convention on Human Rights system: substantial issues}

Let us now look at the contribution and impact of the Ombudsman to the case law of the ECtHR.

National Ombudsmen have an important impact in enhancing the European system of protection of human rights. On one hand, they rely in their practice on the ECHR and other Council of Europe treaties as well as on ECtHR case law. They are non-judicial mechanisms for the domestic application of the ECHR system. The European Ombudsman also uses provisions of the ECHR and ECtHR case law in replying to those complaints against EU institutions and bodies that involve human rights issues.

On the other hand, the Ombudsmen play an important role in the execution of judgments of the ECtHR.

Furthermore, their notifications, decisions, recommendations, reports, and opinions can become point of reference in the judgments of the ECtHR; thus, they not only take what the ECtHR has decided but also help to shape the decisions of the ECtHR and indirectly contribute to it. The ECtHR profits from national/ EU knowledge of the Ombudsman, and, vice versa, ECHR-based knowledge is useful for an Ombudsman. But can the Ombudsman go even further - beyond the 'margin of appreciation' doctrine?

\subsection{An Ombudsman's decision - only a point of reference or part of the reasoning of the ECtHR?}

It happens, and not rarely, that the ECtHR makes reference to the findings of Ombudsmen. However, this is done most of the time in the so-called facts part ('circumstances of the case' or 'relevant domestic law and practice'), not in the reasoning part ('law'), of the ECtHR judgments. Ombudsmen's decisions, reports, and other materials are classified as useful information; it can even happen that these have, in a way, the value of evidence.

For example, concerning Estonia, the ECtHR has on several occasions mentioned the findings of the national Ombudsman in the facts part of the judgment. In the judgment in the case A.T. v. Estonia, ${ }^{*} 35$ the Court referred to an opinion wherein the Estonian Ombudsman addressed the situation of medical examinations in a prison; the Estonian government had also referred to the fact that the Ombudsman had accepted that in some instances constant supervision of a prisoner might be necessary even during a doctor's examination. However, the ECtHR did not repeat the findings of the Ombudsman in its reasoning.

The Greek Ombudsman has observed that a violation of the Convention by Greece as found by the ECtHR in the case Chowdury and Others $v$. Greece ${ }^{*} 36$ could have been avoided, had the measures requested by the Ombudsman been taken. ${ }^{*} 37$ The case involved a serious violation - namely, that of Article 4, §2 ECHR (prohibition of forced labour) - by Greece in a context of foreign land-workers in Manolada. The Judgment of the ECtHR makes extensive reference to the warning addressed by the Greek Ombudsman in 2008 to the then leadership of competent ministries, also in the law part where the Court gives its reasons ${ }^{*} 38$.

In another case, Kummer $v$. The Czech Republic ${ }^{*} 39$, the ECtHR again confirmed a national Ombudsman's findings, this time pertaining to humiliating treatment of a detained man at a police station in the Czech Republic. The case concerned a man who, on his way home from a bar where he had been drinking alcohol, was stopped by a police patrol and, since he had no identity card and in disregard of the fact that he said he lived just a few metres away and could provide his identity card, was taken to the police station,

\footnotetext{
A.T. $v$ Estonia, 23183/15, 13 November 2018 (s 41).

Chowdury and Others $v$ Greece, 21884/15, 30 March 2017.

See the homepage of the Greek ombudsman, at: https://www.synigoros.gr/?i=stp.en.news\&page=8 (accessed 12 April 2020).

See: Chowdury and Others $v$ Greece (n 36) s 112.

Kummer $v$ The Czech Republic, 32133/11, 25 July 2013.
} 
handcuffed to an iron ring on the wall by one hand and later by his other hand too, and kept in a cell for 50 minutes. The only institution on national level to point out the police's mistake was the Ombudsman, who issued a report finding that the police had violated the Police Act in several respects and that there had been no legal grounds for detaining the applicant. The ECtHR found the Czech Republic to be in breach of Article $3 \mathrm{ECHR}^{*} 40$.

In the case Satakunnan Markinnapörssi OY and Satamedia OY v. Finland ${ }^{*} 41$, the Finnish Data Protection Ombudsman requested the Data Protection Board to restrain the applicant companies from processing taxation data in the manner and to the extent they had done and from passing such data to an SMS service. The Data Protection Board dismissed the Ombudsman's request on the grounds that the applicant companies were engaged in journalism. The case subsequently came before the Supreme Administrative Court, which sought a preliminary ruling from the CJEU on the interpretation of the EU Data Protection Directive. ${ }^{*}{ }^{2}$ The CJEU ruled that activities related to data from documents that were in the public domain under national legislation could be classified as 'journalistic activities' if their object is to disclose to the public information, opinions, or ideas, irrespective of the medium used to transmit them. Consequently, the Finnish Supreme Administrative Court directed the Data Protection Board to forbid the processing of taxation data in the manner and to the extent carried out by the applicant companies, thus confirming what the Ombudsman had suggested. The Supreme Administrative Court concluded that, since the decisive factor was assessment of whether the publication contributed to public debate or was solely intended to satisfy the curiosity of readers, the publication of the whole database and the transmission of the information to the SMS service could not be regarded as journalistic activity. In the Convention proceedings, the applicant companies complained of, among other grievances, a violation of Article 10 ECHR. The ECtHR found no violation of the applicants' freedom of expression, thereby confirming the Finnish Data Protection Ombudsman's position, and the ECtHR criticised the applicants for not complying with the Ombudsman's request. The ECtHR also noted that, contrary to what the applicant companies suggested, it emerged clearly from the case file that the Data Protection Ombudsman acted on the basis of concrete complaints from individuals claiming that the publication of taxation data infringed their right to privacy.

From the above analyses, it appears noteworthy that the documents of national Ombudsmen have contributed to the findings of the Court, and, in fact, the Court could even use them more in the future.

\subsection{The Ombudsman: Beyond the 'margin of appreciation' doctrine?}

Ombudsmen can help on national level to reach out to the ECHR and aid in disseminating the ECtHR case law up to the point where this is confirmed by the ECtHR. But can he or she go further than the strict minimum standards provided by the Convention system?

According to some authors, a national Ombudsman can play a role in the leeway given to states in implementing some of their ECHR duties. ${ }^{*} 4$ Even if the ECtHR has not found a violation of the ECHR in a particular case, owing to the margin of appreciation a state may have, the national Ombudsman may find, on the basis of the broader Ombudsman criteria of equity and justice, that the state's conduct falls short of acceptable standards.

Ombudsmen can in certain situations go further and make human-rights-friendly interpretations even if the situation does not per se represent a violation of minimum standards set by the ECHR.

40 Ibid.

41 Satakunnan Markinnapörssi OY and Satamedia OY v Finland [GC] 931/13, 27 June 2017.

42 The Data Protection Law Enforcement Directive, Directive (EU) 2016/680 on the protection of natural persons regarding processing of personal data connected with criminal offences or the execution of criminal penalties, and on the free movement of such data.

43 See, for example: Matti Pellonpää, 'Finnish Parliamentary Ombudsman As Guardian of Human Rights and Constitutional Rights: View from the European Court of Human Rights' in Ilkka Rautio (ed), Parliamentary Ombudsman of Finland 80 Years (Helsinki) 75-76; Linda C Reif (n 21) 125-36. 


\section{The European Ombudsman and the European Court of Human Rights}

There are almost no ECtHR cases involving the European Ombudsman. The European Ombudsman is, notably, mentioned by the ECtHR in a freedom of expression case, Tillack $v$. Belgium ${ }^{*} 44$. The case involved search and seizure operations carried out at the home and office of a journalist suspected of bribing a European Union official. The applicant, a German journalist, was assigned to Brussels to cover European Union policy and the activities of the European institutions. His newspaper published two articles he had written on the basis of information from confidential documents from the European Anti-Fraud Office (OLAF). The articles reported on allegations by a European civil servant pertaining to irregularities in the European institutions and the internal investigations OLAF carried out into those allegations. Suspecting the applicant of having bribed a civil servant to disclose confidential information, OLAF opened, to no avail, an investigation to identify the informant. Then OLAF lodged a complaint against the applicant with Belgian judicial authorities, which initiated an investigation. The applicant's home and workplace were searched; almost all his work papers and tools were seized and placed under seal, and his belongings were not returned.

The applicant filed a complaint with the European Ombudsman. The Ombudsman submitted a special report to the European Parliament in which he concluded that the suspicion of bribes by the applicant had been based on mere rumours spread by another journalist and not, as OLAF had suggested, by Members of the European Parliament. The Ombudsman concluded that OLAF should acknowledge that it had made incorrect and misleading statements.

The ECtHR agreed with the European Ombudsman; it reiterated the importance of protecting journalistic sources for press freedom in a democratic society and found that the searches in this case had amounted to non-justified interference with the applicant's right to freedom of expression. As OLAF's internal investigation had failed to produce the desired result and the suspicion of bribery by the applicant was based on mere rumour, there had been no overriding public interest to justify such measures.

Other judgments of the ECtHR mentioning the European Ombudsman, such as Jeunesse $v$. the Netherlands ${ }^{*} 45$ and Ramadan $v$. Malta, ${ }^{*}{ }^{6}$ merely contain a reference to Article 20 of the Treaty on the Functioning of the European Union (TFEU), on citizenship of the Union, which enshrines, among other rights, the right to apply to the European Ombudsman.

\section{Conclusion}

The title of this article has a double meaning on purpose: 'in the eyes' has a sense defined as 'in the view or opinion of, from the standpoint of', but it also has a second meaning, 'in the centre or focal point of something'. Perhaps this article helps a bit to move the Ombudsman institution in the case law of the Court from the first connotation mentioned to the second one.

The examples analysed above show how intertwined the work of Ombudsmen and that of the Court are. In general, it can be agreed that the Ombudsman institution is neither a remedy to be exhausted before one turns to the Court nor a remedy in the sense of Article 13 ECHR. However, in certain exceptional circumstances, as was the case in Raninen $v$. Finland and Egmez $v$. Cyprus, it would be important not to cut off the applicant's access to the ECtHR simply because he or she, under the specific circumstances or in the absence of any other remedies, turned only to the Ombudsman before bringing an application to the ECtHR. Overall, even if the Ombudsman does not constitute a domestic remedy to be exhausted, the Ombudsman's role is to assist in the domestic remedies and this role is to be taken seriously by the Court.

Maybe there will one day be a necessity in a case before the ECtHR to accept the Ombudsman as an applicant on behalf of the victim of a human rights violation. It would be welcoming to open possibilities, in a limited and not abusive manner, for the Ombudsman to represent an applicant under certain exceptional circumstances (or at least co-represent) and certainly to encourage the Ombudsman to intervene as a third

\footnotetext{
Tillack $v$ Belgium, 20477/05, 27 November 2007.

Jeunesse $v$ the Netherlands, 12738/10, from 4 December 2012 (decision on admissibility) and 3 October 2014, respectively.

46 Ramadan $v$ Malta, 76136/12, 21 June 2016.
} 
party before the Court. This would allow the Ombudsman to make a greater contribution to the case law of the Court.

Ombudsmen sometimes have knowledge and experience of various sorts, related to their possibly broader tasks and their own-initiative competencies, that not only benefit the applicant but would increase the level of protection of human rights in general and improve the co-operation between the Ombudsman and the Court in serving the common goal.

The ECtHR has looked at whether the proceedings before a national Ombudsman meet the requirements for a fair trial as provided by Article 6 ECHR. It goes without saying that the independence and impartiality of Ombudsmen are of crucial significance. Furthermore, the Court has acknowledged the importance of access to the Internet for purposes of consulting the documents of the national Ombudsman. To a lesser extent, the Court has had to deal with questions of the impact of national Ombudsmen on proceedings of the domestic judiciary.

Ombudsmen use the case law of the ECtHR in their work; they play an important role in enforcing the principles of the ECtHR judgments in practice. On the other hand, the ECtHR also uses the work done by Ombudsmen in its judgments.

Notwithstanding the fact that the Ombudsman institution is, apart from in exceptional circumstances, generally not an effective remedy to be exhausted before turning to the ECtHR and not an effective remedy in the sense of Article $13 \mathrm{ECHR}$, it is not rare for the reports of the national Ombudsman to contribute to the proceedings of the ECtHR. The proceedings before the Ombudsman as such but also, above all, his or her substantial findings are regularly taken seriously by the Court, and references are made (although mostly in the facts part, on a few occasions also under the findings in the judgments of the Court). The use of the Ombudsman's decisions depends on the information in the case file, the parties' submissions, the legal system of the respective country the case concerns, and the role and position of the Ombudsman in that country.

In these cases, the Court indirectly gives the Ombudsman's work legal value/force. This 'legal transformation' is of utmost importance in cases where national Ombudsmen have correctly applied the Convention and ECtHR case law. The Court, in referring to Ombudsmen's opinions in the facts part and even using them in its reasoning (albeit rarely), is giving national Ombudsmen and the European Ombudsman alike encouragement to continue paving the challenging road of human rights protection. It is to be welcomed if this encouragement would result in even further and wider protection than that offered by the ECtHR because the Ombudsman can use broader criteria of equity and justice.

The Ombudsman should not only be a bridge between citizens and administration but also be an intermediary between citizens and other human rights protection bodies in Europe.

It is vital to continue communication within the European Network of Ombudsmen ${ }^{*} 47$ while also strengthening the dialogue between the Ombudsmen and the ECtHR. Why not invite Ombudsmen, including the European Ombudsman, together with NGOs, to regular meetings with the ECtHR? There is a role for all to perform - in particular, in situations wherein the rule of law is becoming, regrettably, more and more vulnerable.

Last but not least, besides everyday work with investigations/complaints, the Ombudsmen and courts should be able to see the forest behind the trees, so as to take a more global attitude and, above all, not forget the human being.

It is important to think about the most vulnerable - human rights are not a luxury, and the independence of Ombudsmen and courts is not their privilege but serves those who seek justice. One must also not forget the 'middle class': the ordinary people who need protection, not only the weak and minorities. It is important to reach out to people, make them aware of their human rights, and contribute to the development of human rights culture in general. This human rights culture starts with the home and family; continues in schools and other education establishments; and should be present in all areas of life, including within European and national institutions, who themselves need to show good examples to others by respecting ethics and fundamental values.

47 See the website of the European Ombudsman, at: https://www.ombudsman.europa.eu/en/european-network-of-ombudsmen/ about/en (accessed 2 July 2020). 